Table 3. Seed counts and weights of confirmed $2 x$ and $4 x$ melons.

\begin{tabular}{|c|c|c|c|c|c|c|c|}
\hline \multirow[b]{2}{*}{ Line } & \multirow[b]{2}{*}{ Ploidy } & \multirow[b]{2}{*}{ No. plants } & \multirow[b]{2}{*}{ No. fruit } & \multicolumn{2}{|c|}{ No. seed/fruit } & \multicolumn{2}{|c|}{ Total seed wt $(g)$} \\
\hline & & & & Range & Mean & Range & Mean \\
\hline C879-J2 & $2 x$ & 6 & 9 & $279-571$ & 417.6 & $8.3-16.3$ & 12.7 \\
\hline $\begin{array}{l}\text { C879-J2-H10 } \\
\text { Planters }\end{array}$ & $4 x$ & 8 & 26 & $15-305$ & 94.5 & $0.5-4.4$ & 2.0 \\
\hline Jumbo & $2 \mathrm{x}$ & 14 & 14 & $338-716$ & 496.9 & $6.6-21.4$ & 14.5 \\
\hline C883-m6 & $4 x$ & 4 & 18 & $45-229$ & 116.5 & $0.9-5.5$ & 2.9 \\
\hline $67-1-100$ & $4 x$ & 8 & 8 & $24-179$ & 89.1 & $0.5-5.3$ & 2.3 \\
\hline
\end{tabular}

Fast and accurate visual identification of $4 \mathrm{x}$ plants, without measurements, is essential to the development of commercially useful lines. By using characteristics such as those described and illustrated, accurate identification of $4 \mathrm{x}$ melons is possible. This procedure reduces the need for more difficult and time-consuming chromosome counts. Ail three $4 \mathrm{x}$ lines reported will be useful in improving this germplasm and the development of new germplasm sets. As new lines are identified, they can be tested for potential use in the development of inbred lines, hy- brids, or parents for the production of triploid (3x) hybrids. likely will be especially useful as a female for production of $3 \mathrm{x}$ and $4 \mathrm{x}$ germplasm. It will be particularly helpful in large, fieldscale research and commercial seed production without hand pollination. With this technique, all hybrid seedlings from $4 \mathrm{x}$ virescent plants will be normal green, in contrast to parental-type yellow seedlings having the recessive virescent trait. Initial attempts to cross $4 \mathrm{x}$ melon plants with $2 \mathrm{x}$ plants have
The recently discovered $4 \mathrm{x}$ virescent line thus far resulted in fruit with hollow seedcoats in the first generation and no 3x plants.

\section{Literature Cited}

Batra, S. 1952. Induced tetraploidy in melons. J. Hered. 43:141-148.

Dumas de Vaulx, R. 1974. Étude des possibilités d'utilisation de la polyploidie dans l'amélioration du melon [ Cucumis melo L.]. Ann. Amelior. Plantes 24:389-403.

Ervin, CD. 1941. A study of polysomatry in Cucumis melo. Amer. J. Bot. 28:113-124.

Kubicki, B. 1962. Polyploidy in melons [Cucumis melo L.] and cucumbers [ Cucumis sativus L.]. Genetica Polonica 3-2:161-179.

Love, S.L., B.B. Rhodes, and P.E. Nugent. 1986. Controlled pollination transfer of a nuclear malesterile gene from a diploid to a tetraploid watermelon line. Euphytica 35:633-638.

Nugent, P.E. 1987. C879-J1 and C879-J2 virescent mutant melon breeding lines. HortScience 22:333-335.

Shifriss, O. 1942. Polyploids in the genus Cисиmis. J. Hered. 33:144-152.

HORTSCIENCE 27(1):50-51. 1992.

\title{
Field Reaction of Landrace Components of Red Mottled Beans to Common Bacterial Blight
}

\author{
James S. Beaver \\ Department of Agronomy, University of Puerto Rico, Mayaguez, \\ PR 00709 \\ James R. Steadman \\ Department of Plant Pathology, University of Nebraska, Lincoln, \\ NE 68583
}

\section{Dermot P. Coyne Department of Horticulture, University of Nebraska, Lincoln, NE 68583 \\ Additional index words. Phaseolus vulgaris, Xanthamonas campestris pv. phaseoli, germplasm, disease resistance}

\begin{abstract}
Field reaction of 25 red mottled bean ( Phaseolus vulgaris L.) genotypes to common bacterial blight [Xanthomonas campestris pv. phaseoli (Smith) Dye] was evaluated in Puerto Rico over 2 years. The average disease severity (percent leaf area with symptoms) was similar over years. The determinate red mottled genotypes had almost twice as much disease as indeterminate genotypes. Eight of the indeterminate genotypes had significantly less disease than the mean of the field experiments. These genotypes may serve as useful sources of resistance to common bacterial blight. The size of the chlorotic zone around necrotic lesions varied between growing seasons, showing that environment can influence the expression of common bacterial blight symptoms.
\end{abstract}

Common bacterial blight $(\mathrm{Cbb})$ is a serious disease in tropical and temperate bean

Received for publication 19 Feb. 1991. Research supported in part by USAID/BIFAD Bean/Cowpea CRSP grant no. AID/DSAN-XII-G-0261. The cost of publishing this paper was defrayed in part by the payment of page charges. Under postal regulations, this paper therefore must be hereby marked advertisement solely to indicate this fact. growing regions (Beaver et al., 1985; Coyne and Schuster, 1974; Schieber, 1970). Most red mottled beans grown in the Dominican Republic are susceptible to common bacterial blight, but the characteristic chlorotic border around the necrotic leaf lesions often has not been observed on certain 'Pompadour'-type red mottled genotypes. The red mottled landrace cultivars, mostly grown by small-scale farmers, have been found to vary for several important traits, including growth habit, leaf pubescence, and biological $\mathrm{N}$ fixation capacity (Catano, 1990; Oviedo et al., 1990). The possibility that disease reaction could also vary led to the objective of this research: to evaluate a group of selections from the Dominican red mottled bean landrace for necrotic and chlorotic field reaction to common bacterial blight.

Twenty-five determinate and indeterminate red mottled bean genotypes were evaluated in Puerto Rico for field reaction to common bacterial blight in 1988 and 1989 . Two red kidney genotypes, 27R and 3M152 , were also planted as susceptible controls. The experiments were planted at the Isabela Substation on 31 Oct. 1988 and 11 Oct. 1989. A randomized complete block design with five replications was used. Experimental units consisted of one 1.5-m row planted with 15 seed. Plots were evaluated for disease severity 46 days after planting in 1988 and 58 days after planting in 1989. All genotypes were at the early to mid-pod-fill stage of development when visually evaluated for percentage of leaf area showing necrosis and water-soaking due to $\mathrm{Cbb}$. In addition, the size of the chlorotic zones surrounding the $\mathrm{Cbb}$ lesions was rated using a scale where $1=$ no chlorotic zone and $5=$ a chlorotic zone surrounding and nearly as large as the necrotic lesion. Rainfall and temperatures were normal and, therefore, favorable for disease development. Natural infection on the susceptible genotypes became prominent shortly after flowering. The average disease severity was similar between years. The disease severity on the susceptible controls ranged from $24 \%$ to $34 \%$ (Table 1). The small plots with five replications provided an adequate level of precision to detect significant disease severity differences among genotypes. Moreover, the disease se- 
Table 1. Common blight severity and chlorotic zone scores of 27 bean genotypes evaluated at Isabela, Puerto Rico, during 1988 and 1989.

\begin{tabular}{|c|c|c|c|c|c|c|c|}
\hline \multirow{2}{*}{ Genotype } & \multirow{2}{*}{$\begin{array}{l}\text { Growth } \\
\text { habit }^{2}\end{array}$} & \multicolumn{3}{|c|}{ Common blight severity } & \multicolumn{3}{|c|}{ Chlorotic zone score ${ }^{\mathrm{x}}$} \\
\hline & & 1988 & 1989 & Mean & 1988 & 1989 & Mean \\
\hline Pompadour $\mathrm{G}$ & I & 10 & 13 & 12 & 2.9 & 1.6 & 2.3 \\
\hline & I & 12 & 6 & $9^{*}$ & 3.0 & 1.2 & 2.1 \\
\hline U & I & 46 & 16 & 30 & $4.5^{*}$ & 1.4 & 3.0 \\
\hline $\mathrm{N}$ & I & 8 & 8 & $8^{*}$ & 2.9 & 2.0 & 2.5 \\
\hline $\mathrm{H}$ & I & 9 & 8 & $9^{*}$ & 3.0 & 1.6 & 2.3 \\
\hline $\mathrm{R}$ & I & 11 & 21 & 16 & 2.8 & 1.4 & 2.1 \\
\hline & $\mathrm{I}$ & 10 & 16 & 13 & 3.1 & 1.8 & 2.5 \\
\hline L & I & 13 & 9 & $11^{*}$ & 3.2 & 1.2 & 2.2 \\
\hline $\mathrm{J}$ & I & 19 & 20 & 20 & 3.2 & $3.0^{*}$ & 3.1 \\
\hline $\mathrm{T}$ & I & 12 & 7 & $9^{*}$ & 2.8 & 2.0 & 2.4 \\
\hline $\mathrm{p}$ & I & 13 & 12 & 13 & 3.2 & 1.6 & 2.5 \\
\hline K & I & 9 & 10 & $10^{*}$ & 3.1 & 2.6 & 2.9 \\
\hline Rocio A & I & 11 & 10 & $11^{*}$ & 2.7 & 2.4 & 2.6 \\
\hline Pompadour Al & I & 5 & 16 & $11^{*}$ & 3.0 & 2.0 & 2.5 \\
\hline Mean & & & & $\overline{12}$ & 31 & $\ddot{18}$ & \\
\hline 8738-01B & D & 19 & 23 & 21 & 19 & 18 & 19 \\
\hline 8738-03B & D & 23 & 17 & 20 & $1.8^{*}$ & $\begin{array}{l}1.0 \\
1.6\end{array}$ & 1.7 \\
\hline $8738-04 B$ & D & 21 & 15 & 18 & 1.9 & 1.8 & 1.9 \\
\hline 8738-05B & D & 24 & 22 & 23 & $1.5^{*}$ & 1.4 & 1.5 \\
\hline 8738-07B & D & 22 & 26 & 24 & $1.4^{*}$ & 1.8 & 1.6 \\
\hline 8738-08B & D & 27 & 24 & 25 & 2.4 & 2.8 & 2.6 \\
\hline $8738-12 B$ & D & 25 & 29 & 27 & 2.3 & $3.2^{*}$ & 2.7 \\
\hline Pompadour $\mathrm{N}$ & D & 37 & 33 & 35 & $1.8^{*}$ & 2.6 & 2.2 \\
\hline Indiana Roja & D & 19 & 23 & 21 & 2.7 & 2.2 & 2.5 \\
\hline Pompadour $\mathrm{F}$ & D & 18 & 13 & 15 & 2.0 & 1.6 & 1.8 \\
\hline Pomp. Checa & $\bar{D}$ & 16 & 12 & 14 & 2.4 & 2.0 & 2.2 \\
\hline Mean & & & & 20 & 2.0 & 2.0 & \\
\hline \multirow{2}{*}{$\begin{array}{l}27 \mathrm{R} \\
3 \mathrm{M}-152\end{array}$} & D & 33 & 26 & 30 & $3.6^{*}$ & 2.6 & 3.1 \\
\hline & D & 34 & 24 & 29 & 3.5 & 1.8 & 2.7 \\
\hline & & & & $\cdots$ & $\cdots$ & - & \\
\hline Mean & & & & 30 & 3.6 & 2.2 & \\
\hline Overall mean & & 19 & 17 & 18 & 2.7 & 2.0 & \\
\hline \multicolumn{2}{|l|}{$L_{S D_{0,0 S}}$} & & & 6 & \multicolumn{2}{|c|}{0.8} & \\
\hline
\end{tabular}

${ }^{2}$ Growth habit score, where $\mathrm{D}=$ determinate and $\mathrm{I}=$ indeterminate.

ypercent of leaf area with necrosis and/or water-soaking.

${ }^{\times}$Score for chlorotic zones around lesions, where $1=$ no chlorotic zone and $5=$ chlorotic zone as large as lesion.

*Significantly different $(P=0.05)$ from the overall mean.

verity of the individual red mottled landrace components was similar between years (Table 1).

As a group, the determinate genotypes had almost twice the disease severity as the indeterminate genotypes (Table 1). Eight of the indeterminate genotypes had significantly less disease than the mean of the test, whereas the disease severity of the determinate lines was equal to or greater than the mean of the test. The difference in disease severity between growth habits could not be attributed to differences in maturity, as most of the determinate and indeterminate lines in the experiment flowered and matured within a few days of each other. The indeterminate lines with low $\mathrm{Cbb}$ severity may serve as useful sources of resistance to not only $\mathrm{Cbb}$ but also to rust [Uromyces appendiculatus (Pers.) Unger pv. appendiculatus] since all of these genotypes have also been selected for dense abaxial leaf pubescence, a trait as- sociated with rust resistance (Oviedo et al., 1990). Greater resistance to $\mathrm{Cbb}$ and rust would be needed to allow the greater yield potential of indeterminate genotypes to be realized (Beaver et al., 1985).

In 1988, the red kidney control genotypes, $27 \mathrm{R}$ and $3 \mathrm{M}-152$, produced typical chlorotic zones around the lesions, and the chlorotic zone around lesions on indeterminate genotypes was larger than that on determinate genotypes (Table 1). In 1989, however, the chlorotic zones were smaller than those in 1988, and there was no significant difference between growth habits or among genotypes. The environment may have affected the degree of expression of the chlorotic zone around the lesions. The halo in the blight of beans caused by Pseudomonas syringae pv. phaseolicola (Burkholder) is expressed more at 20C than at higher temperatures (Coyne and Schuster, 1974). Researchers familiar with Cbb symptoms on beans in temperate or higher-altitude tropical environments should know that chlorotic zones around lesions are often not expressed on beans grown in the lowland tropics. The size of the chlorotic zone around necrotic lesions can vary between growing seasons and among bean genotypes in field evaluations.

\section{Literature Cited}

Beaver, J.S., C. Paniagua, D. Coyne, and G. Freytag. 1985. Yield stability of dry bean genotypes in the Dominican Republic. Crop Sci. 25:923-926.

Beaver, J.S., C.V. Paniagua, J.R. Steadman, and R. Echavez-Badcl. 1985. Reaction of dry bean genotypes to natural infection of foliar diseases in the Dominican Republic. J. Agr. Univ. of Puerto Rico 69:283-290.

Cataño, H. 1990. Selection of Phaseolus vulgaris L. genotypes able to nodulate in the presence of nitrogen. MS Thesis, Univ. of Puerto Rico, Mayaguez.

Coyne, D.P. and M.L. Schuster. 1974. Breeding studies of tolerance to several bean (Phaseolus vulgaris L.) bacterial pathogens. Euphytica 23:651-666.

Oviedo, F., J.S. Beaver, and J.R. Steadman. 1990. Caracterizacion de la pubescencia acicular en las hojas de genotipos de habichuela. J. Agr. Univ. of Puerto Rico. 74:111-119.

Schieber, E. 1970. Enfermedades de1 frijol (Phaseolus vulgaris) en la Republica Dominicana. Turrialba 20:20-23. 